\title{
In vitro antimalarial activity of extracts of some plants from a biological reserve in Costa Rica
}

\author{
Misael Chinchilla ${ }^{1}$, Idalia Valerio ${ }^{1}$, Ronald Sánchez ${ }^{2}$, Víctor Mora², Vanessa Bagnarello ${ }^{1}$, \\ Laura Martínez ${ }^{1}$, Antonieta Gonzalez ${ }^{2}$, Juan Carlos Vanegas ${ }^{1} \&$ Álvaro Apestegui ${ }^{1}$ \\ 1. Laboratorio de Investigación Universidad de Ciencias Médicas "Dr. Andrés Vesalio Guzmán" (UCIMED), San José, \\ Costa Rica, América Central; chinchillacm@ucimed.com,valerioci@ucimed.com, bagnarellomv@ucimed.com, \\ martinezel@ucimed.com,vanegaspj@ucimed.com, avapest@gmail.com \\ 2. Sección de Biología, Sede Occidente, Universidad de Costa Rica, San José, Costa Rica, América Central; \\ ronald.rsr@gmail.com, agpaniagua@gmail.com
}

Received 27-V-2011. Corrected 20-IX-2011. Accepted 21-X-2011.

\begin{abstract}
Treatment with the usual antimalarial drugs, have induced parasite resistance, reinforcing the need to finding natural antimalarial components that would be found on plants from the forest. Therefore, we decided to look for these components in Costa Rican plants from a protected forest area. Fresh and dry extracts of roots, bark, leaves, flowers and fruits of 25 plants from a biological reserve in Costa Rica, Reserva Biológica Alberto Manuel Brenes (REBAMB), were studied in vitro for the presence of substances with antimalarial activity. By studying the inhibition of $P$. berghei schizogony, we assessed the antimalarial activity of several plant extracts: Aphelandra aurantiaca, A. tridentata (Acanthaceae); Xanthosoma undipes (Araceae); Iriartea deltoidea (Arecaceae); Neurolaena lobata (Asteraceae); Senna papillosa, Pterocarpus hayessi, Lonchocarpus pentaphyllus (Fabaceae); Nectandra membranacea, Persea povedae, Cinamomum chavarrianum (Lauraceae); Hampea appendiculata (Malvaceae); Ruagea glabra, Guarea glabra (Meliaceae); Psidium guajava (Myrtaceae); Bocconia frutescens (Papaveraceae); Piper friedrichsthalii (Piperaceae); Clematis dioica (Ranunculaceae); Prunus annularis (Rosaceae); Siparuna thecaphora (Siparunaceae); Solanum arboreum, Witheringia solanacea (Solanaceae); Ticodendrum incognitum (Ticodendraceae); Heliocarpus appendiculatus (Tiliaceae) and Myriocarpa longipes (Urticaceae). We used different parts of the plants as well as fresh and dried extracts for testing IC50. The solid content of the extracts ranged from $1-71.9 \mu \mathrm{g} / \mathrm{mL}$. The fresh extracts showed stronger activity than the dry ones. Since the plants showing the strongest antimalarial activity are very common in Central America, and some similar genera of these plants have shown positives results in South America, we considered important to present these findings for discussion. On the other hand, this is the first systematic study of this kind ever realized in a circumscribed and protected area of Costa Rica. Rev. Biol. Trop. 60 (2): 881-891. Epub 2012 June 01.
\end{abstract}

Key words: malaria, antimalarial plants, in vitro antimalarial activity, Costa Rican plants, Plasmodium berghei.

Malaria is a very important tropical disease, with a reported human morbidity approaching 300-500 million worldwide and a mortality of 1-2 million deaths per year (WHO 2005, Wrigth 2005). Plasmodium falciparum, the most pathogenic representative of this species, is responsible for the great majority of cases (Tramputz et al. 2003, Batista et al. 2009, Kakkilaya 2008). Confirming this fact, the geographical areas where this species is more frequent, such as Africa, also have the greater incidence of deaths due to malaria infection.

From 1973-1983, Costa Rica implemented strong antimalarial programs, that virtually eradicated the disease and the incidence became near zero for many years (Vargas 2001). The epidemiological control was neglected for the same reason and new infection outbreaks 
appeared again, as a consequence of disordered immigrations and immune deficiencies in segments of the population (AIDS). The outbreaks are not as important as they were in 19912000 , but are certainly increasing with time (Trejos et al. 2010).

Unfortunately, continuous and frequent treatments with antimalarial drugs, such as chloroquine, have induced parasite resistance (Baird 2004), reinforcing the need for finding more natural antimalarial components. We believe that the best candidates for that would be found on plants from the forest.

Besides, the World Health Organization (WHO), aiming to reduce parasite resistance and to find natural products for this purpose, has promoted research in this area (Simpson 2002, Anthony et al. 2005). Quinine was the first natural drug found for malaria treatment, but because of its high toxicity, its use is limited to only some very qualified cases (WHO 2010). For $P$. falciparum resistant strains, the alternative treatment actually is the use of artemisin derivatives from plants of the genus Artemisia. (Kakkilaya 2008, WHO 2010). Research has continued in laboratories of many developed as well as undeveloped countries (Saxena et al. 2003). Several studies regarding this matter have made important contributions to this subject in the past in Costa Rica (Castro et al. 1996, Chinchilla et al. 1998, 2001, 2003).

While, in Africa and Asia there have been many studies that have reported active substances against P. falciparum (Pillay et al. 2008, Soh \& Benoit-Vical 2007). In Latin-America most of the studies came from South America (Krettli et al. 2001, Botsaris 2007, Valadeu et al. 2009 among others) and very few from Central America (Kohler et al. 2002, Franssen et al. 1997); we believe that our study represents a new contribution to this scientific area.

WHO and OPS (Organización Panamericana de la Salud) recommend, as an official model for research with antimalarial components, the use of Plasmodium berghei strains (Ramesar et al. 2008).

Based on the previous knowledge, we decided to perform a more integral study of
Costa Rican plants for antimalarial activity. We choose to work in a more protected and less disturbed forest area called "Reserva Biológica Alberto Manuel Brenes” (REBAMB).

This study have three fundamental objectives: 1) Reveal the natural diversity present in REBAMB, 2) Demonstrate the importance of our biodiversity in ethnobotany, especially concerning the treatment of important diseases, such as malaria, and finally, 3) disseminate our studies, in an attempt to help the discovery of new drugs that could improve human health.

\section{MATERIAL AND METHODS}

Plants: A total of 25 different plants (Table 1) were collected from October 2007-December 2008 in the biological reserve, previously mentioned (REBAMB), owned by the University of Costa Rica. This reserve is located 42km Northeast from San Ramón, (10¹3'49', N - 8436'10" W), Alajuela, Costa Rica, with an altitude that varies from 600-1 640 meters above sea level, and an average temperature of $21^{\circ} \mathrm{C}$, a relative humidity of $98 \%$ and rainfall of $3461 \mathrm{~mm}$ per year, thus representing a variety of climates and ecological niches (Sánchez 2000).

Plants were selected according to previous works (Sittenfeld et al. 1999, Chinchilla et al. 2008) that showed that extracts obtained from insects feeding from certain plants, had antimalarial activity. Identification and selection of those host families and species was definitive in choosing the plants for this study.

All the plants were identified by an expert botanist, who based his findings on previous publications (Gómez-Laurito \& Ortíz 2004, Barrantes 2004), the geographical location was established with the help of a GPS. All the fresh material collected, was carefully labeled and stored at our herbarium in UCIMED. A photographic register and phenologic analysis was performed for all plants directly in the field.

In all cases, the samples obtained consisted of bark, roots, young and mature leaves, as well as flowers and ripe or unripe fruits. All these materials were placed in individual 
TABLE 1

Families and species of plants from the REBAMB with antimalarial activity

\begin{tabular}{|c|c|c|}
\hline Family & Species & Actividad* \\
\hline Acanthaceae & Aphelandra aurantiaca (Scheidw.) Lindl. Laura Martínez 18. & Inactive \\
\hline Acanthaceae & Aphelandra tridentata Hemsl. Laura Martínez 19 & Active \\
\hline Araceae & Xanthosoma undipes (K. Koch \& C.D. Bouché) K. Koch Laura Martínez 15. & Inactive \\
\hline Arecaceae & Iriartea deltoidea Ruiz \& Pav. Laura Martínez 16 & Inactive \\
\hline Asteraceae & Neurolaena lobata (L.) Cass. Laura Martínez 23 & Very active \\
\hline Fabaceae & Senna papillosa (Britton \& Rose) H.S. Irwin \& Barneby Laura Martínez 33. & Active \\
\hline Fabaceae & Pterocarpus hayesii Hemsl. Laura Martínez 12. & Inactive \\
\hline Fabaceae & Lonchocarpus pentaphyllus (Poir.) Kunth ex DC. Laura Martínez 24. & Inactive \\
\hline Lauraceae & Nectandra membranacea (Sw.) Griseb. Laura Martínez 7. & Very active \\
\hline Lauraceae & Persea povedae W.C. Burger Laura Martínez 14. & Active \\
\hline Lauraceae & Cinnamomum chavarrianum (Hammel) Kosterm. Laura Martínez 28. & Active \\
\hline Malvaceae & Hampea appendiculata (Donn. Sm.) Standl. Laura Martínez 1. & Very active \\
\hline Meliaceae & Ruagea glabra Triana \& Planch. Laura Martínez 4. & Active \\
\hline Meliaceae & Guarea glabra Vahl Laura Martínez 26. & Inactive \\
\hline Myrtaceae & Psidium guajava L. Laura Martínez 26. & Very active \\
\hline Papaveraceae & Bocconia frutescens L. Laura Martínez 2 & Very active \\
\hline Piperaceae & Piper friedrichsthalii C. DC. Laura Martínez 13. & Inactive \\
\hline Ranunculaceae & Clematis dioica L. Laura Martínez 11. & Active \\
\hline Rosaceae & Prunus annularis Koehne .: Laura Martínez 10 & Inactive \\
\hline Siparunaceae & Siparuna thecaphora (Poepp. \& Endl.) A. DC. Laura Martínez 38 & Very active \\
\hline Solanaceae & Solanum arboreum Dunal Laura Martínez 22 & Active \\
\hline Solanaceae & Witheringia solanacea L’Hér. Laura Martínez 30. & Very active \\
\hline Ticodendraceae & Ticodendron incognitum Gómez-Laur. \& L.D. Gómez Laura Martínez 8. & Active \\
\hline Tiliaceae & Heliocarpus appendiculatus Turcz. Laura Martínez 3. & Inactive \\
\hline Urticaceae & Myriocarpa longipes Liebm. Laura Martínez 9. & Inactive \\
\hline
\end{tabular}

*Very active: less than $5 \mu \mathrm{g} / \mathrm{mL}$, Active: $>5$ to $50 \mu \mathrm{g} / \mathrm{mL}$, Weakly active: $>50$ to $100 \mu \mathrm{g} / \mathrm{mL}$, Inactive: $>100 \mu \mathrm{g} / \mathrm{mL}$.

plastic bags and transported in a cold container to the laboratory.

Each part of the plant was further divided into two portions: one was kept as fresh material, while the other was dried for subsequent analysis.

Preparation of extracts: The fresh material coming from all parts of the plants was carefully washed and then finely chopped; the other portion was dried and prepared as a coarse powder in order to ease extraction. For screening purposes, we used $15 \mathrm{~g}$ of fresh or $10 \mathrm{~g}$ of dried material. They were placed in separate $250 \mathrm{~mL}$ amber bottles, and then extracted with $100 \mathrm{~mL}$ of $70 \%$ ethanol for a week at room temperature, with occasional agitation. These extracts, were vacuum filtered through a Buchner funnel using Whatman 1 paper and then concentrated at $40^{\circ} \mathrm{C}$ with a rotary evaporator (Buchi R-114); this procedure completely eliminated ethanol.

\section{In vitro antimalarial assay:}

- Parasite strain: A P. bergheis strain (NK 65) obtained from American Type Culture Collection (ATCC) was used to assess the antimalarial activity of the extracts. This strain was kept alive by weekly 
re-infection in Swiss mice following the recommendations given by WHO for these type of studies.

- Experimental animals: Male and female mice (Mus musculus Swiss) weighing $22-24$ g originally obtained from the University of Costa Rica were used through the experiments. The animals were maintained in an air-conditioned environment in the animal house of UCIMED, feeding with standard pet food and drinking water ad libitum. They were caged in groups of 5-10 and all studies were performed in agreement with international rules for laboratory animal use, under the ACCMAL control in Costa Rica.

- Inoculum: Parasitized erythrocytes were obtained from a previously infected mouse by cardiac puncture using heparin as anticoagulant and then diluted in RPMI 1640 medium, supplemented with $10 \%$ fetal calf serum plus antibiotics (RPMI 1640). Animals were inoculated by intraperitoneal injection with a blood suspension $(0.2$ $\mathrm{mL}$ ) containing $10^{6}-10^{7}$ parasitized erythrocytes. After $24 \mathrm{~h}$ infection, mice showing a parasitic presence in blood of ten to $15 \%$ of the erythrocytes infected with ring stages, were used in all the in vitro studies.

- In vitro antimalarial assays: We followed general procedures for $P$. berghei culture and also for testing in vitro antimalarial effect (Ager et al. 1984, Deharo et al. 2000). Briefly, erythrocytes (final cell suspension $1 \%, \mathrm{v} / \mathrm{v}$, blood/culture medium), from a one day infected mice, suspended in RPMI 1640 medium, were mixed with the intact plant extracts $(0.05 \mathrm{~mL}$ blood and $0.05 \mathrm{~mL}$ diluted extract per well), the mixture was transferred to plates and then incubated in a candle jar at $37^{\circ} \mathrm{C}$ for $24 \mathrm{~h}$ in a low speed shaker (Mini-Shaker 3D Boeco, Germany). For each experiment we used a positive control with chloroquine in standard concentration and a negative control with only culture medium.
To determine the $\mathrm{IC}_{50}$ (minimal concentration that inhibits $50 \%$ of parasite schizogony), we made serial dilutions of the extract according to the dry weight obtained in each case. After the incubation period, we made blood smears from each well, stained with Giemsa dye, and the number of schizonts was determined by counting at least 500 red blood cells under the microscope's 100X objective. The percentage of the parasite schizogony inhibition was calculated by the following formula (Deharo et al. 2000):

Schizogony inhibition $(\%)=$ schizonts in control schizonts with extract x 100/ schizonts in control.

For calculations and statistical analysis the Probit method (Deharo et al. 2000, Diaz et al. 2004) was used. To classify the activity levels of each extract the Rasoanaivo table (1999) was used. Accordingly the term "very active" means a IC50 less than $5 \mu \mathrm{g} / \mathrm{mL}$; active from $>5-50 \mu \mathrm{g} /$ $\mathrm{mL}$; "weakly active" from $>50-100 \mu \mathrm{g} / \mathrm{mL}$ and "inactive" more than $100 \mu \mathrm{g} / \mathrm{mL}$.

\section{RESULTS}

The crude alcoholic extracts obtained from the different plant structures of the 25 varieties studied (Table 1) showed some antimalarial activity (Fig. 1). The plants with the highest activity consistently showed it in both fresh and dried material. Not all plant structures showed the antimalarial effect. Figure 2 show the percentages of plants with one, two, three, four or more structures with potential effect against $P$. berghei.

There were more plants showing antimalarial activity in only one type of structure, (Figs. 2, 3) but three plants showed it in four or more parts. When comparing extracts of fresh and dried plant with antimalarial activity (Fig. 3 ), no significant differences were found for structures, except in flowers and young leaves where the dry material showed higher antimalarial activity. Root fresh extracts showed more activity as well. 


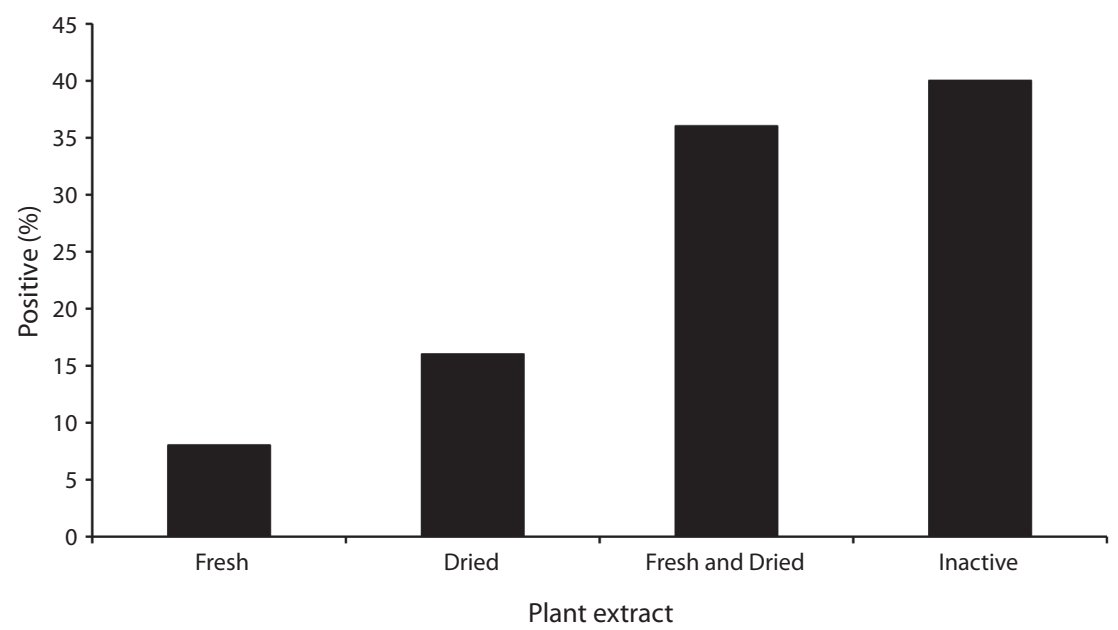

Fig. 1. Percentage of plants with antimalarial activity from the REBAMB according to the type of extract studied.

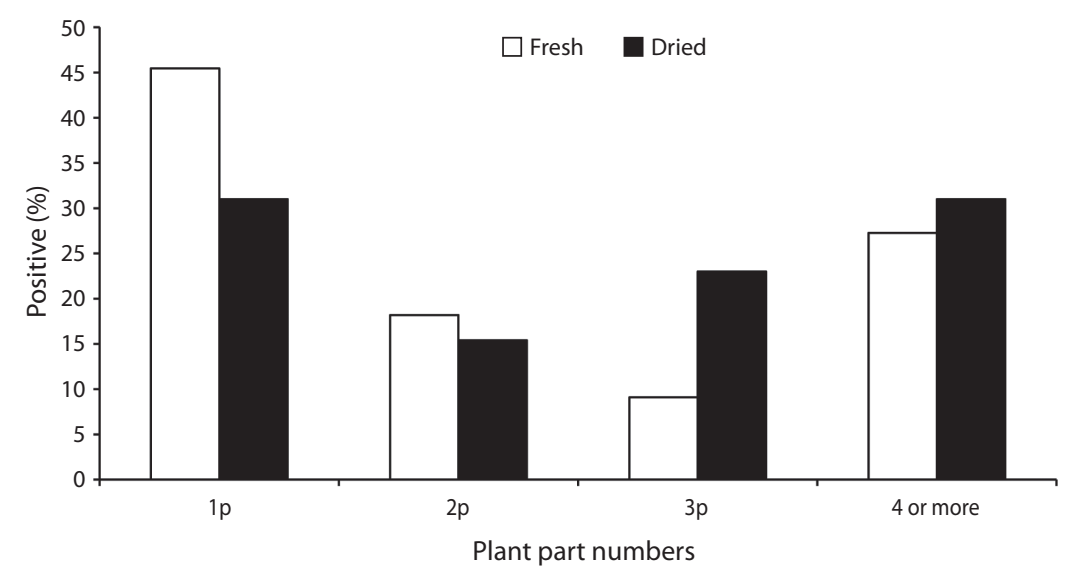

Fig. 2. Distribution of plants according to the number of parts in each of them that showed antimalarial activity: fresh and dried extracts.

IC50 tests on fresh (Table 2) and dried extracts (Table 3 ) yielded the results presented in figure 4. Fresh material (Fig. 4A) showed the highest antimalarial activity ("very active") as compared to the other categories; it was also independent of the part of the plant studied. In contrast, for dry samples (Fig. 4B), the "active" category presented higher values than the others, again regardless of the plant structure studied.

\section{DISCUSSION}

Several authors have pursued the search for natural products with antimalarial effect in plants in the past and in recent years (Rafatro et al. 2005, Ogbonna et al. 2008, Pillay et al. 2008, Kayser et al. 2003). The rationale for such studies is based on the resistance of the parasites to conventional treatment as observed in the case of malaria (Fidock et al. 2008). 


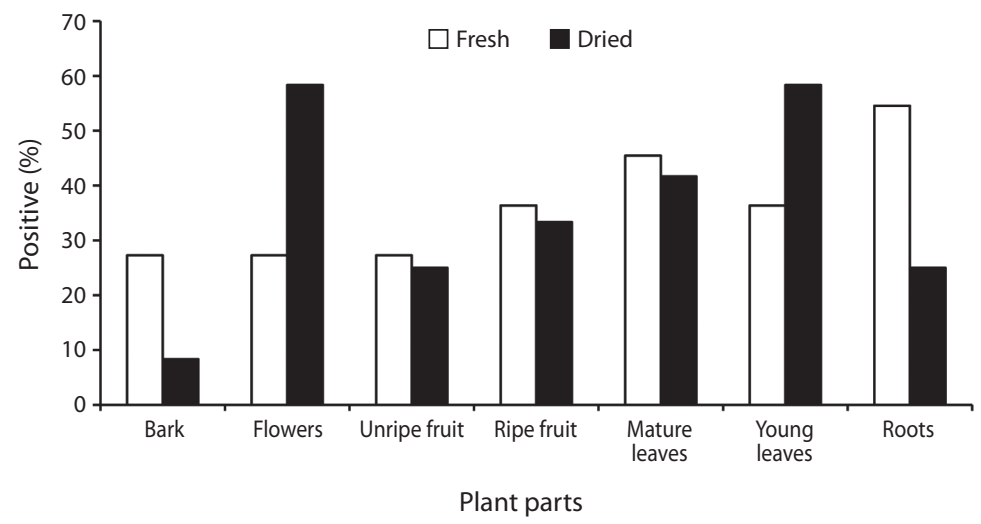

Fig. 3. Relationship between the antimalarial activity found in fresh and dry extracts of positive plants.

TABLE 3

In vitro activity $\mathrm{IC}_{50}(\mu \mathrm{g} / \mathrm{mL})$ on $P$. berghei of dried extracts

\begin{tabular}{|c|c|c|c|c|c|c|c|}
\hline Species & B & $\mathrm{F}$ & UF & RF & YL & ML & $\mathrm{R}$ \\
\hline B. frutescens & & 16.9 & 5.5 & 8.8 & 17.2 & & \\
\hline C. chavarrianum & 38.7 & & 10.5 & & 7.4 & 39.8 & \\
\hline C. dioica & & & & & & 19.1 & \\
\hline H. appendiculata & & 5.3 & & & & & \\
\hline N. membranacea & & 54.3 & 8.2 & & 1.6 & 3.8 & \\
\hline N. lobata & & 4.3 & & & 8.9 & & \\
\hline$P$. povedae & 20.1 & & & 5.4 & 16.5 & 34.4 & 31.8 \\
\hline P. guajava & & 1 & & 6.2 & & 8 & \\
\hline R. glabra & & & & & 41 & & 39.1 \\
\hline S. papillosa & & 19.9 & & & & 14.1 & 14.3 \\
\hline S. thecaphora & & 12.8 & 9.8 & & 15.5 & & \\
\hline S. arboreum & & & & 3.5 & & & \\
\hline W. solanacea & & & & & 1.6 & & \\
\hline
\end{tabular}

B: bark, F: flowers, UF: unripe fruit, RF: ripe fruit, YL: young leaves, ML: mature leaves, R: root.

This resistance began with $P$. falciparum near the ' 60 s and today is extremely common, especially in Africa, Central and South America (Bloland 2001). This resistance has also been documented for P. vivax (Baird 2004, Anstey et al. 2009) the most common species found outside Africa (Wells et al. 2010) and in Costa Rica, were reports account for $95-98 \%$ of the cases (Vargas 2001).

Malaria parasites also exhibit resistance to Fansidar, a treatment involving Sulfadoxine and Pyrimethamine, that act inhibiting the formation of nucleic acids (Bloland 2001, Hastings 2004, Kakkilaya 2008).

Based on the foregoing, we started in Costa Rica the search for antimalarial components in plants, as previously documented (Chinchilla $e t$ al. 1998, 2001, Castro et al. 1996).

In conducting this research, we took into account not only the traditional observations on the treatment of malaria and its symptoms, but also the findings of a previous study 
TABLE 2

In vitro activity $\left(\mathrm{IC}_{50}, \mu \mathrm{g} / \mathrm{mL}\right)$ on $P$. berghei of plant fresh extracts

\begin{tabular}{|c|c|c|c|c|c|c|c|}
\hline Species & B & $\mathrm{F}$ & UF & $\mathrm{RF}$ & YL & ML & $\mathrm{R}$ \\
\hline A. tridentata & & & & & & 4.9 & 25.1 \\
\hline B. frutescens & 5.9 & 2.8 & 2.4 & 4.6 & 15.2 & 2.2 & 2.6 \\
\hline H. appendiculata & & & & & & & 3.9 \\
\hline N. membranacea & 71.9 & 2.2 & & 10.7 & 0.8 & & 3.2 \\
\hline N. lobata & & & & & 4.1 & & \\
\hline P. povedae & & & & & & 9.7 & \\
\hline P. guajava & & & 5.3 & & & 8.2 & \\
\hline S. thecaphora & 2 & & 1 & 3.9 & & & 50.8 \\
\hline S. papillosa & & & & 0.9 & & & \\
\hline T. incognitum & & & & & 3.3 & 9.1 & 7 \\
\hline W. solanacea & & 1.3 & & & & & \\
\hline
\end{tabular}

B: bark, F: flowers, UF: unripe fruit, RF: ripe fruit, YL: young leaves, ML: mature leaves, R: root.

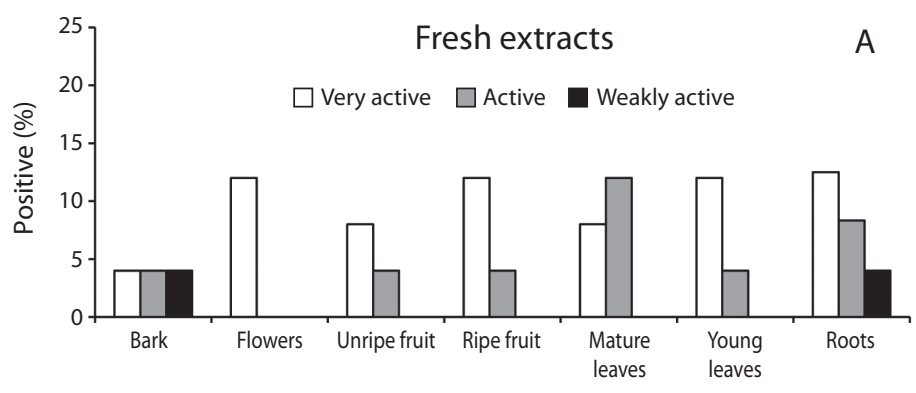

Plant parts

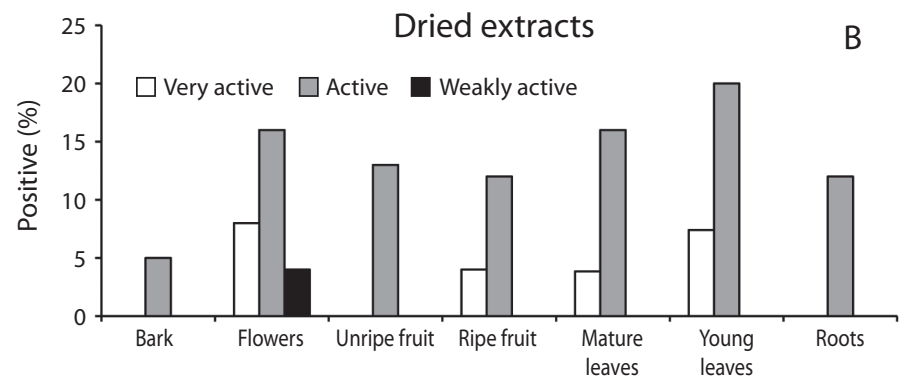

Plant parts

Fig. 4. Relationship between the strength of antimalarial activity and plant parts studied. 
(Chinchilla et al. 2008), in which, antimalarial activity was found in extracts of certain arthropods, especially those that feed on plants during any stage of its life cycle. The plants found as a feeding source of these insects, guided us in choosing species or similar families as the ones studied in this investigation. This selection system led us to obtain $60 \%$ positivity in the 25 plants tested.

Very few papers in other countries mention plants with higher antimalarial activity than the ones found in this work. It could be explained by the fact that these plants are characteristically from Central America (Jenett-Siems et al. 1999), and no other researchers have done any work with them.

H. appendiculata is found only in Panama, Honduras and Costa Rica (Tropicos 2010) and T. incognitum is a recently classified plant that has not been tested for antiparasitic activity. $S$. thecaphora, N. membranaceae and B. frutescens have a greater distribution in the Americas, but were not found in any other places (Tropicos 2010). In Africa and Asia there has been an intense and enthusiastic search for active compounds against $P$. falciparum especially (Aderounmu 2002, Mariath et al. 2009, Titanji et al. 2008); the opposite is true in America where many of the studies come from South America (Krettli et al. 2001, Rodríguez-Pérez et al. 2006, Batista et al. 2009, Valadeau et al. 2009 among others) and very few from Central America (Franssen 1997, Kohler et al. 2002). Antimalarial components have been found in S. andina, S. pauciflora, S. tonduziana and $S$. aspera, but not in $S$. thecaphora. The present study represents an important contribution to this field since the data obtained, together with that already reported, has shown to be inedited.

Most of the studies mentioned, have focused their attention in just a few parts of the plant, but we studied every plant structure, included bark, roots, leaves and fruits in order to optimize the results.

Almost every one of the studies referred before used dried material for extraction. Since the traditional way of using plants for healing is by using fresh material (Blair \& Madrigal
2005, Togola et al. 2005) we included this modality as part of our research. Shows that the activity in different structures of the plant was very similar independently of the use of the dry or fresh extract. However, when analyzing the potency of IC50, the fresh material showed, except for bark and mature leaves, a dominance of the condition "very active" over "active". The opposite is true for dry extracts; it can be deducted that although the antimalarial activity was detectable in both types of extracts, the potency of this activity appears to decrease by drying the structure. The implication of this observation concludes that if only dry samples were to be studied, some plants with antimalarial activity could be missed.

Since this study was performed in a biological reserve, there is a guarantee for the permanence, for many years, of plants with active components against malaria. In addition, all samples were collected in a fairly restricted area, which reduces the risk of changes due to external factors such as climate, soil type and other (Martin 2001). Factors such as stage of development of the plant and the presence of arthropods, also might affect the data, since the plant needs to synthesize new metabolites in order to defend from them (Coley \& Barone 1996). These metabolites could also be active against malaria parasites, but this will be the subject of analysis in other publications.

This work seeks to offer a contribution to Ethnobotany applied to Medical Sciences in Costa Rica, as has been done in many other countries (Martin 2001). Studies in progress are being made for identifying the chemical component(s) responsible for the antimalarial effect of the plant extracts.

\section{ACKNOWLEDGMENTS}

This study was supported in part by a grant (Proyect Forinves 18) of the Consejo Nacional para Investigaciones Científicas y Tecnológicas (CONICIT), Research Department of the Universidad de Ciencias Médicas (UCIMED) and Centro Regional de Occidente, Universidad de Costa Rica. Special thanks to Laura 
Valerio, Jose Bolaños, Edwin Valenciano and Hugo Pérez as well as to some students from UCIMED for their work in the development of all project phases.

\section{RESUMEN}

El tratamiento con las drogas antimaláricas de uso común han inducido resistencia por parte del parásito, lo que obliga a buscar en las plantas de los bosques, componentes naturales con actividad en contra de esta enfermedad. Por lo tanto, decidimos buscar dichos componentes en plantas de una Reserva Forestal de Costa Rica. Extractos tanto frescos como secos de raíz, corteza, hojas, flores y frutos, de 25 plantas de la Reserva Biológica Alberto Manuel Brenes (REBAMB), fueron estudiados in vitro en busca de sustancias con actividad antimalárica. Las plantas estudiadas fueron: Aphelandra aurantiaca, A. tridentata (Acanthaceae); Xanthosoma undipes (Araceae); Iriartea deltoidea (Arecaceae); Neurolaena lobata (Asteraceae); Senna papillosa, Pterocarpus hayessi, Lonchocarpus pentaphyllus (Fabaceae); Nectandra membranacea, Persea povedae, Cinamomum chavarrianum (Lauraceae); Hampea appendiculata (Malvaceae); Ruagea glabra, Guarea glabra (Meliaceae); Psidium guajava (Myrtaceae); Bocconia frutescens (Papaveraceae); Piper friedrichsthalii (Piperaceae); Clematis dioica (Ranunculaceae); Prunus annularis (Rosaceae); Siparuna thecaphora (Siparunaceae); Solanum arboreum, Witheringia solanacea (Solanaceae); Ticodendrum incognitum (Ticodendraceae); Heliocarpus appendiculatus (Tiliaceae) y Myriocarpa longipes (Urticaceae). Los extractos frescos y secos de las diferentes partes de las plantas fueron estudiadas y se determinó la IC50, el cual osciló entre 1-71.9mg/mL; los extractos frescos mostraron mayor actividad antimalárica. Las plantas que presentaron mayor actividad son muy comunes en Centroamérica y algunos géneros similares, aunque no las mismas especies, han sido encontrados positivos en América del Sur; por esta razón consideramos importante estos resultados como información y materia de discusión en este tema. Además este es el primer estudio sistemático de esta naturaleza realizado en un área boscosa circunscrita y protegida de Costa Rica.

Palabras clave: malaria, antimaláricos, in vitro, plantas, Costa Rica, Plasmodium berghei.

\section{REFERENCES}

Aderounmu, A.O. 2002. The antimalarial activity of the crude organic extract of four commonly used Nigerian medicinal plants. (Accessed: 17 August 2010, adeolasmalariaresearch.files.wordpress.com/.../ medicinal-plants-1_blog.doc).
Ager, J.R., W. Peters \& W.H.G. Richards. 1984. Rodent malaria models in antimalarial drugs. I. Biological background, experimental methods, and drug resistance. Handbook. Exp. Pharmacol. 68: 225-264.

Anstey, N.M., B. Russell, T.W. Yeo \& R.N. Price. 2009. The pathophysiology of vivax malaria. Trends. Parasitol. 25: 220-227.

Anthony, J.P., L. Fyfe \& H. Smith. 2005. Plant active components-a resource for antiparasitic agents. Trends. Parasitol. 21: 462-468.

Baird, J.K. 2004. Choroquine resistance in Plasmodium vivax. Antimicrob. Agents. Chemother. 48: 4075-4023.

Barrantes, T. 2004. Flora del Sotobosque de la Reserva Biológica Alberto Manuel Brenes. Coordinación Investigación sede acreditada, Universidad de Costa Rica, Costa Rica.

Batista, R., A. Silva \& A. Braga de Oliveria. 2009. Plantderived antimalarial agents: New leads and efficient phytomedicines. Part II. Non-Alkaloidal Natural Products. Molecules 14: 3037-3072.

Blair, S. \& B. Madrigal. 2005. Plantas Antimaláricas de Tumaco Costa Pacífica Colombiana. Universidad de Antioquía, Colombia.

Bloland, P.B. 2001. Drug resistance in malaria. World Health Organization, Geneva, Switzerland.

Botsaris, A. 2007. Plants used traditionally to treat malaria in Brazil: the archives of Flora Medicinal. J. Ethnobiol. Ethnomed. 3: 18-23.

Castro, O., M. Barrios, M. Chinchilla \& O.M. Guerrero.1996. Evaluación química y biológica del efecto de extractos de plantas contra Plasmodium berghei. Rev. Biol. Trop. 44: 361-367.

Chinchilla, M., O.M. Guerrero, G. Tamayo, A. Sittenfeld, A. Jiménez \& I. Valerio. 2008. Concentración natural de compuestos antimaláricos en artrópodos tropicales (in Vitro). Rev. Biol. Trop. 56: 473-485.

Chinchilla, M., O.M. Guerrero, G. Abarca, M. Barrios \& O. Castro. 1998. An in vivo model to study the antimalaric capacity of plant extracts. Rev. Biol. Trop. 46: 35-39.

Chinchilla, M., O.M. Guerrero, G. Tamayo \& A. Sittenfeld. 2001. Empleo de técnicas y materiales biológicos en la búsqueda de productos activos contra la malaria. Información Tecnológica 12: 187-192. 
Chinchilla, M., M. Herrera, O.M. Guerrero, A. Jiménez, G. Tamayo, A. Sittenfeld, V. Nielsen \& P. Hurtado. 2003. Efecto de extractos de artrópodos sobre la multiplicación del Toxoplasma gondii dentro de macrófagos peritoneales de ratón. Rev. Biol. Trop. 51: 317-320.

Coley, P.D. \& J.A. Barone. 1996. Herbivory and plant defences in tropical forest. Annu. Rev. Ecol. Syst. 27: 305-335.

Deharo, E., P.H. Gautret, V. Muñoz \& M. Sauvain. 2000. Técnicas de laboratorio para la selección de sustancias antimaláricas. Pérez, La Paz, Bolivia.

Díaz, M.C., G.D. Bulus \& Y. Pica. 2004. Ensayos toxicológicos y métodos de evacuación de calidad de aguas. G. Castillo (ed.). Bogotá, Colombia.

Fidock, D.A., R.T. Eastman, S.A. Ward \& S.R. Meshnick. 2008. Recent highlights in antimalarial drug resistance and chemotherapy research. Trends. Parasitol. 24: $537-544$

Frederich, M., M. Tits \& L. Angenot. 2008. Potential antimalarial activity of indole alkaloids. Trans. R. Soc. Trop. Med. 102: 11-19.

Franssen, F.F.J., L.J.J.W. Smeijsters, I. Berger \& B.E. Medinilla. 1997. In vivo and In vitro antiplasmodial activities of some plants traditionally used in Guatemala against Malaria. Antimicrobiol. Ag. Chemother. 41: 1500-1503.

Gómez-Laurito, J. \& R. Ortiz. 2004. Lista con anotaciones de las Angiospermas de la Reserva Biológica Alberto Brenes (Microcuencas de los ríos San Lorenzo y San Lorencito), Costa Rica. Lankesteriana 4: 113-142.

Hastings, I.M. 2004. The origins of antimalarial drug resistance. Trends Parasitol. 20: 512-518.

Jenett-Siems, K., P. Mockenhaupt, U. Bienzie, M. Gupta \& E. Eich. 1999. In vitro antiplasmodial activity of Central American medicinal plants. Trop. Med. Int. Health 4: 611-615.

Kakkilaya, B.S. 2008. Malaria Site. (Downloaded: 15 January 2011, http://www.malariasite.com/malaria/ history_treatment.htm).

Kayser, O., A.F. Kiderien \& S.L. Croft. 2003. Natural products as antiparasitic drugs. Parasitol. Res. 90: S55-S62.

Kohler, I., K. Jennett-Siems, M.A. Hernández, R.A. Ibarra, W.G. Berendsohn, U. Bienzle \& E. Eckart. 2002. In vitro antiplasmodial investigation of medicinal plants from El Salvador. Z. Naturforsh 57: 277-281.
Krettli, A.U., V.F. Andrade-Neto, M.G. Brandão \& W.M. Ferrari. 2001. The search for new antimalarial drugs from plants used to treat fever and malaria or plants ramdomly selected: a review. Mem. Inst. Oswaldo Cruz 96: 1033-1042.

Mackintosh, C.L., J.G. Beeson \& K. Marsh. 2004. Clinical features and pathogenesis of severe malaria. Trends. Parasitol. 20: 1471-4822.

Mariath, I.R., H.S. Falcao, J.M. Barboza-Filho, L.C.F. de Sousa, A.C.A. Tomas, L.M. Batista, M.F.M. Dimiz, P. Athayde-Filho, J.F. Tavarez, M.S. Silva \& E.V.L Cuahes. 2009. Plants of the American continent with antimalarial activity. Rev. Bras. Farmacol. 19: 158-191.

Martin, G.J. 2001. Etnobotánica: manual de métodos. Pueblos y plantas. no. 1. Nordan- Comunidad, Montevideo, Uruguay.

Ogbonna, D.N., G. Tojibiye, A. Sokari \& A. Agomuoh. 2008. Antimalarial activities of some selected traditional herbs from South Eastern Nigeria against Plasmodium species. Res. J. Parasitol. 3: 25-31.

Pillay, P., V.J. Maharaj \& P.J. Smith. 2008. Investigating South African plants as a source of new antimalarial drugs. J. Ethnopharmacol. 119: 438-54.

Rafatro, H., R.B. Robijaona, A.S. Razafimahefa, A.M. Rosoamahenina, E.K. Ramanantosoa, H. Rakotoarimanana, M.H. Rakotondrabe, M. Raminosoa, A. Rakotozafy, J. Ranaivoravo, J.F. Rajaonarison, S. Ratsimamanga, G. Tona, G.K. Mesia, S. Derese \& J.O. Midiwo. 2005. Screening of plant extracts for searching antiplasmodial activity. $11^{0}$ Napreca Symposiun Book of Proceeding Antananarivo, Madagascar.

Ramesar, J., C. Jense \& A. Waters. 2008. Methods in Plasmodium berghei Research 4: The Plasmodium berghel research model of malaria. (Downloaded: 17 August 2010, http://www.lumc.nl/rep/cod/ redirect/1040/research/malaria/modelll).

Rasoanaivo, P., S. Ratsimamanga-Urverg, D. Ramanitrahasimbola, H. Rafatro \& A. Rakoto-Ratsimamanga. 1999. Criblaged'extraits de plantes de Madagascar pour recherche d'activite antipaludique et d'effet potentialisateur de la chloroquine J. Ethnopharm. 64: 117-126.

Rodríguez-Pérez, M., J.M. Martinez, L.R. Rivero, M.H. Alvarez, A.F.C. Valdez, D.A. Rodríguez, R.S. Lizama \& J.A. Payrol. 2006. Evaluación de la actividad antimalárica de algunas plantas utilizadas en la medicina tradicional cubana. Rev. Ciênc Farm. Apl. 27: 197-205. 
Sánchez, R. 2000. Reserva Biológica Alberto Manuel Brenes. San Ramón, Alajuela, Costa Rica. MINAE, San José, Costa Rica.

Saxena, S., N. Pant, D.C. Jain \& R.S. Bhakuni. 2003. Antimalarial agents from plant sources. Curr. Sc. 85: 1314-1329.

Simpson, I., 2002. To beat resistance to antimalarials switch to combination medicines Bull. WHO. 80: 523.

Sittenfeld, A., G. Tamayo, V. Nielsen, A. Jiménez, P. Hurtado, M. Chinchilla, O.M. Guerrero, M.A. Mora, M. Rojas, R. Blanco, E. Alvarado. J.M. Gutiérrez \& D.H. Janzen. 1999. Costa Rican international cooperative biodiversity group: using insects and other arthropods in biodiversity prospecting. Pharmac. Biol. 37: 55-68.

Soh, P.N. \& F. Benoit-Vical. 2007. Are West African plants a source of future antimalarial drugs? J. Ethnopharm. 114: $130-140$.

Titanji, V.P.K., D. Zofou \& M. Ngemenya. 2008. The Antimalarial potential of medicinal plants used for the treatment of malaria in Cameroonian folk medicine. Afr. J. Treda. CAM. 5: 302-321.

Togola, A., D. Diallo, S. Dembelé, H. Barsett \& B.S. Paulsen. 2005. Ethnopharmacological study of the different uses of seven medicinal plants from Mali (Africa Occidental) in the regions Doila, Kolokani y Siby. J. Ethnobiol. Ethnomedic. 1: 7-15.

Tramputz, A., M. Jereb, I. Muslovic \& R.M. Prabhu. 2003. Severe Malaria. J. Cardioth. Surg. 7: 315-323.
Trejos, M.E., T. Solano, R. Céspedes, R.M. Vargas \& R. Bejarano. 2010. Boletín semanal de vigilancia de la salud. Semana epidemiológica \# 3 (7 al 16 de enero 2010). Dirección vigilancia de la salud. Ministerio de Salud. San José, Costa Rica.

Tropicos.Org. Missouri Botanical Garden. (Downloaded: 05 August 2010, http://www.tropicos.org).

Valadeau, C., A. Pabon, E. Deharo, J. Albán-Castillo, Y. Estevez, F.A. Lores, R. Rojas, D. Gamboa, M. Sauvain, D. Castillo \& G. Bourdy. 2009. Medicinal plants from the Yanesha (Perú): Evaluation of the leishmanicidal and antimalarial activity of selected extract. J. Ethnomedic. 123: 413-422.

Vargas, M. 2001. Diagnóstico situacional de la malaria y el uso del DDT en Costa Rica. OPS/OMS, San José, Costa Rica.

Wells, T.N.C., J.N. Burrows \& K. Baird. 2010. Targeting the hypnozoite reservoir of Plasmodium vivax: the hidden obstacle to malaria elimination. Trends. Parasitol. 26: 145-151.

WHO. 2005. World Malaria Report, World Health Organization, Geneva, Switzerland. (Downloaded: 8 October 2007, http:77www.rbm.who.int/wmr2005).

WHO. 2010. Guidelines for the treatment of malaria. World Health Organization, Geneva, Switzerland. (Downloaded: 8 October 2007, http://www.who.int/malaria/ publications/atoz/9789241547925/en/index.html.).

Wright, C.W. 2005. Plant derived antimalarial agents: New leads and challenges. Phytoch. Rev. 4: 55-61. 
